\title{
Article
}

\section{Inhibitory Effects of Bacterial Silk-like Biopolymer on Herpes Simplex Virus Type 1, Adenovirus Type 7 and Hepatitis C Virus Infection}

\author{
Esmail M. El-Fakharany ${ }^{1, * \mathbb{D}}$, Marwa M. Abu-Serie ${ }^{2}$, Noha H. Habashy ${ }^{3}$, Nehal M. El-Deeb ${ }^{4}$, \\ Gadallah M. Abu-Elreesh ${ }^{5}$ (D), Sahar Zaki ${ }^{5}$ and Desouky Abd-EL-Haleem ${ }^{5}$
}

check for

updates

Citation: El-Fakharany, E.M.; Abu-Serie, M.M.; Habashy, N.H.; El-Deeb, N.M.; Abu-Elreesh, G.M.; Zaki, S.; Abd-EL-Haleem, D. Inhibitory Effects of Bacterial Silk-like Biopolymer on Herpes Simplex Virus Type 1, Adenovirus Type 7 and Hepatitis C Virus Infection. J. Funct. Biomater. 2022, 13, 17. https:// doi.org/10.3390/jfb13010017

Academic Editors:

Sandra Varnaitė-Žuravliova, Jolanta Sereikaitè,

Julija Baltušnikaitè-Guzaitienè and Vijay Kumar Thakur

Received: 15 November 2021 Accepted: 30 December 2021 Published: 2 February 2022

Publisher's Note: MDPI stays neutral with regard to jurisdictional claims in published maps and institutional affiliations.

Copyright: (C) 2022 by the authors. Licensee MDPI, Basel, Switzerland. This article is an open access article distributed under the terms and conditions of the Creative Commons Attribution (CC BY) license (https:// creativecommons.org/licenses/by/ $4.0 /)$.
1 Proteins Research Department, Genetic Engineering and Biotechnology Research Institute (GEBRI), City of Scientific Research and Technological Applications, Alexandria 21934, Egypt

2 Medical Biotechnology Department, Genetic Engineering and Biotechnology Research Institute (GEBRI), City of Scientific Research and Technological Applications, Alexandria 21934, Egypt; marwaelhedaia@gmail.com

3 Biochemistry Department, Faculty of Science, Alexandria University, Alexandria 21511, Egypt; noha.habashi@alexu.edu.eg

4 Biopharmacetical Products Research Department, Genetic Engineering and Biotechnology Research Institute, City of Scientific Research and Technological Applications, Alexandria 21934, Egypt; nehalmohammed83@gmail.com

5 Environmental Biotechnology Department, Genetic Engineering and Biotechnology Research Institute (GEBRI), City of Scientific Research and Technological Applications, Alexandria 21934, Egypt; g_abouelrish@yahoo.com (G.M.A.-E.); saharzaki@yahoo.com (S.Z.); abdelhaleemm@yahoo.de (D.A.-E.-H.)

* Correspondence: esmailelfakharany@yahoo.co.uk

\begin{abstract}
Bacterial polymeric silk is produced by Bacillus sp. strain NE and is composed of two proteins, called fibroin and sericin, with several biomedical and biotechnological applications. In the current study and for the first time, the whole bacterial silk proteins were found capable of exerting antiviral effects against herpes simplex virus type-1 (HSV-1), adenovirus type 7 (AD7), and hepatitis $\mathrm{C}$ virus (HCV). The direct interaction between bacterial silk-like proteins and both HSV-1 and AD7 showed potent inhibitory activity against viral entry with $\mathrm{IC}_{50}$ values determined to be 4.1 and $46.4 \mu \mathrm{g} / \mathrm{mL}$ of protein, respectively. The adsorption inhibitory activity of the bacterial silk proteins showed a blocking activity against HSV-1 and AD7 with $\mathrm{IC}_{50}$ values determined to be 12.5 and $222.4 \pm 1.0 \mu \mathrm{g} / \mathrm{mL}$, respectively. However, the bacterial silk proteins exhibited an inhibitory effect on HSV-1 and AD7 replication inside infected cells with $\mathrm{IC}_{50}$ values of 9.8 and $109.3 \mu \mathrm{g} / \mathrm{mL}$, respectively. All these results were confirmed by the ability of the bacterial silk proteins to inhibit viral polymerases of HSV-1 and AD7 with $\mathrm{IC}_{50}$ values of 164.1 and $11.8 \mu \mathrm{g} / \mathrm{mL}$, respectively. Similarly, the inhibitory effect on HCV replication in peripheral blood monocytes (PBMCs) was determined to be $66.2 \%$ at concentrations of $100 \mu \mathrm{g} / \mathrm{mL}$ of the bacterial silk proteins. This antiviral activity against $\mathrm{HCV}$ was confirmed by the ability of the bacterial silk proteins to reduce the ROS generation inside the infected cells to be $50.6 \%$ instead of $87.9 \%$ inside untreated cells. The unique characteristics of the bacterial silk proteins such as production in large quantities via large-scale biofermenters, low costs of production, and sustainability of bacterial source offer insight into its use as a promising agent in fighting viral infection and combating viral outbreaks.
\end{abstract}

Keywords: bacterial silk; biopolymer proteins; antiviral; HSV-1; adenovirus; HCV

\section{Introduction}

Natural products have gathered special attention because of the surviving biodiversity of flora worldwide and the luxury of obtaining extracts and crude forms from these sources with the help of technological innovation [1,2]. In addition to collagen, polymeric silk is one of the most plentiful naturally derived macromolecular protein polymers obtained mainly from animal origins [3]. More than 120,000 metric tons of silks are manufactured 
worldwide annually, and the main manufacturers are located in China, India, and Japan [4]. Polymeric silk is a natural protein of importance in medical applications and commercial life. Increased uses of bacterial polymeric silk-like proteins are expected in the near future for several reasons such as low cost-effect, rapid secretion, and modest product recapture. Silk proteins consist mostly of two types of proteins in a core-shell type shape: fibroin composes the core and is enclosed by the glue-like sericin, which cements itself to the fibroin fibers. Sericin, a major constituent of silk proteins, is selectively removed as waste material from silk fiber throughout the silk manufacturing process to make silk more lustrous. Commonly, the removal of sericin from fiber leads to the formation of industrial byproducts that are disposed of as waste materials, causing environmental pollution and constituting a huge waste of natural resources. Thus, sericin will need to be recovered and recycled in an adequate manner to provide social and significant economic benefits [5]. Sericin is easily hydrolyzed although it is considered an insoluble protein in cold water. Sericin is an useful protein owing to its unique features such as oxidation resistance, antibacterial potential, UV resistance, capacity to absorb and release moisture easily, and tyrosine kinase inhibitory activity [6-12]. Sericin is also a glycoprotein that possesses many biological characteristics, including antioxidation, immunomodulation, and inhibition of elastase and tyrosinase activities. Recently, sericin was found to reduce reactive oxygen species (ROS), protect normal cells from oxidative damage caused by UVB radiation, and inhibit tumor progression, being a strong antibacterial candidate $[13,14]$. Meanwhile, researchers suggest that viruses are the most abundant biological entities on the planet [15]. Currently, millions of people are infected with different viruses, and many of these people are not receiving treatment or vaccination such as infection with retroviruses [16,17]. Enveloped viruses consist of a protein coat called a capsid that surrounds central genetic material, which is either DNA or RNA and is unable to replicate without a host cell. Therefore, to survive, viruses must infect cells and use these cells to replicate themselves. In the manner of doing this, they can kill these cells and cause damage to the host organism, which is why viral infections can make people ill. Hepatitis C virus (HCV), adenovirus type 7 (ADV7), and herpes simplex virus type 1 (HSV1) infections are universal serious diseases, and they lead to several hepatic sequels, death, and genital herpes [18-20].

The high cost of viral disease treatment and/or vaccinations leads to patients using alternative remedies as a traditional medicine for viral infection control. There are many examples of traditional medicine such as the use of camel milk for HCV treatment [21], as camel milk contains many important proteins that play a crucial role in viral prevention [22-24]. In addition, there are many microbial metabolites are used as effective compounds in viral treatment, including mushroom and cyanobacterial lectins [25-28]. Medical usage of natural bioactive ingredients as a main source of treatment to date is well known, even considering the great contribution of chemotherapeutic drugs to modern therapy. However, there is no information on the potential effects of the silk proteins of animal or bacterial origin on viral diseases such as infection with HCV, HSV-1, and AD7. If either one of these proteins could be shown to be effective against pathogenic viruses, it might be a more affordable source for use in medicinal/pharmacological applications, thus contributing to providing a sustainable production and reduction in medical costs.

In this study, we evaluated the antiviral inhibitory activity of whole bacterial silk proteins in an obtained silk of nonanimal origin, which was produced by Bacillus sp. strain NE (a petroleum-originated bacteria) [10,29]. This antiviral effect was measured to investigate the ability of the whole bacterial silk proteins as a nonanimal silk source, produced by Bacillus sp. strain NE, to inhibit the infection of HSV-1, ADV7, and HCV, viruses that cause a severe challenge to the worldwide public health system owing to their limited vaccination or symptomatic treatment. 


\section{Materials and Methods}

\subsection{Whole Bacterial Polymeric Silk-like Protein Isolation and Silk-like Protein Preparation}

The bacterial polymeric silk-like proteins were produced by Bacillus sp. strain NE as previously identified according to Kamoun et al. [29]. In brief, Bacillus sp. strain NE was inoculated in $100 \mathrm{~mL}$ nutrient broth (SNB) medium (containing $500 \mathrm{~mL}$ of nutrient broth and $500 \mathrm{~mL}$ mineral salt solution per liter). A $500 \mathrm{~mL}$ salt solution was prepared by mixing various salts $\left(\mathrm{K}_{2} \mathrm{HPO}_{4}, 5.0 \mathrm{~g} ; \mathrm{KH}_{2} \mathrm{PO}_{4}, 20 \mathrm{~g} ; \mathrm{NaCl}, 0.1 \mathrm{~g} ;\left(\mathrm{NH}_{4}\right)_{2} \mathrm{SO}_{4}, 30 \mathrm{~g} ; \mathrm{FeSO}_{4} \cdot 7 \mathrm{H}_{2} \mathrm{O}\right.$, $\left.0.01 \mathrm{~g} ; \mathrm{CaCl}_{2} \cdot 2 \mathrm{H}_{2} \mathrm{O}, 0.01 \mathrm{~g} ; \mathrm{MgSO}_{4} \cdot 7 \mathrm{H}_{2} \mathrm{O}, 0.2 \mathrm{~g} ; \mathrm{MnSO}_{4} \cdot 7 \mathrm{H}_{2} \mathrm{O}, 0.2 \mathrm{~g} ; \mathrm{MnSO}_{4} \cdot \mathrm{H}_{2} \mathrm{O}, 0.002 \mathrm{~g}\right)$ $\mathrm{CaCl}_{2} \cdot 2 \mathrm{H}_{2} \mathrm{O}, 0.01 \mathrm{~g}$; glucose, $0.03 \%(w / v)$ (Fluka Chemie, Gillingham, UK); and yeast extract, $0.03 \%(w / v)$ [30], and it was incubated at $30{ }^{\circ} \mathrm{C}$ overnight in a shaker incubator at $150 \mathrm{rpm}$. Then, $5 \mathrm{~mL}$ of bacterial culture was inoculated in $100 \mathrm{~mL}$ TSM (containing per liter: $5 \mathrm{~g}$ of KNO3, $30 \mathrm{~g}$ trypticase soy broth, and $20 \mathrm{~g}$ of L-glutamic acid) production medium and incubated for 5 days under the same conditions. The formed exo-biopolymer was precipitated by centrifugation of the cultured media for $30 \mathrm{~min}$ at $8000 \mathrm{rpm}$. After the crude supernatant was concentrated by a rotary evaporator and dialyzed against distilled water at $4{ }^{\circ} \mathrm{C}$ overnight, about $30 \mathrm{~mL}$ cold ethanol was added to $10 \mathrm{~mL}$ of dialyzed concentrate. Then, the precipitate was mixed with $10 \%$ cetylpyridinium chloride (CPC) during gentle stirring. The obtained broth was left under room conditions for several hours to obtain the polymeric precipitate by centrifugation at $5000 \mathrm{rpm}$ for $30 \mathrm{~min}$. The precipitate was dissolved in $0.5 \mathrm{M}$ of sodium chloride to obtain the polymeric broth. The polymeric broth was lyophilized after washing three times with cold ethanol to obtain the purified bacterial polymeric-like silk proteins [29].

\subsection{Serum Sample Collection}

HCV-4a patient serum samples used in this investigation were obtained from the Institute of Medical Research, Alexandria, Egypt. Serum samples were stored at $-80{ }^{\circ} \mathrm{C}$ prior to viral inoculation experiments. The patients' written consent and approval for this study were obtained from the institutional ethics committee.

\subsection{Human Peripheral Blood Mononuclear Cell Separation}

Peripheral blood mononuclear cells (PBMCs) were separated from whole human blood using gradient centrifugation by Ficoll-Paque Plus (MP Biomedicals, Illkirch, France) as reported by Lohr et al. [31]. Briefly, whole blood sample was 5 times diluted using freshly prepared PBS and then overlaid dropwise on Ficoll. The monolayer of PBMCs was separated using gradient centrifugation at $2000 \mathrm{rpm}$ for $30 \mathrm{~min}$. The recovered cells were collected and washed 3 times using PBS.

\subsection{Cytotoxicity Assays}

African green monkey kidney epithelial cell line (Vero cells) was obtained from American Type Culture Collection (ATCC) via VACSERA (Cairo, Egypt). Vero cells were cultured in DMEM medium and used as adenovirus type 7 (ADV7) and herpes simplex virus type 1 (HSV-1) host cells. While PBMCs (hepatitis C virus (HCV) host cells) were cultured in RPMI medium. Silk protein cytotoxicity was tested on both Vero cells and PBMCs using MTT assay [32,33]. Briefly, both Vero cells and PBMCs were seeded in 96-well cell culture plates at densities of $10^{4}$ and $10^{5}$ cells/well and incubated at $37^{\circ} \mathrm{C}$ in $5 \% \mathrm{CO}_{2}$ for $24 \mathrm{~h}$. After incubation, serial dilutions of the tested silk protein were incubated with Vero and PBMCs for $72 \mathrm{~h}$. Serial dilutions of the HSV-1 and ADV7 standard drugs (ribavirin and acyclovir, respectively) were incubated with Vero cells for $72 \mathrm{~h}$. At the end of incubation, $20 \mu \mathrm{L}$ of $5 \mathrm{mg} / \mathrm{mL}$ MTT (Sigma, St. Louis, MO, USA) was added to each well and the plates were incubated at $37^{\circ} \mathrm{C}$ for $3 \mathrm{~h}$. After discarding MTT solution, $100 \mu \mathrm{L}$ DMSO (dimethyl sulfoxide) was added and the dye intensity was quantified using the automated ELISA microplate reader adjusted to $570 \mathrm{~nm}$ to quantify the cell viability [26,34]. The effective safe concentration $\left(\mathrm{EC}_{100}\right)$ doses (at 100\% cell viability) of the tested protein were estimated by the GraphPad Prism 9 InStat software. 


\subsection{The Antiviral Activity of Silk Proteins against ADV7 and HSV-1}

Ten-fold dilutions of ADV7 and HSV-1, separately, were incubated with a monolayer of Vero cells in 96-well plates for $2 \mathrm{~h}$ in a $5 \% \mathrm{CO}_{2}$ incubator. At the end of incubation, the unabsorbed viruses were aspirated and replaced with DMEM containing $10 \%$ FBS. Then, the plates were incubated in a $5 \% \mathrm{CO}_{2}$ incubator for 3 days. MTT assay was used to determine cell viability (\%), as described above, in the infected and uninfected cells to calculate $\mathrm{TCID}_{50}(50 \%$ tissue culture infectious dose) using the formula of the Ramakrishnan method [35].

\subsubsection{MTT and RT-qPCR Assays for Investigation of Antiviral Activity of Silk Protein}

The utilized 100TCID 50 (100 times the TCID 50 ) viral inocula $\left(10^{-4}\right.$ and $10^{-3}$ for ADV7 and HSV-1, respectively) were used to test the mode of antiviral action of silk protein. For assessment of the direct virucidal effect, different concentrations of silk protein and standard drugs were incubated for $2 \mathrm{~h}$ with HDV7 and HSV-1, before being added to the Vero cell monolayer in a 96-well plate. The adsorption inhibition effect was evaluated by pretreating the host cells with serial dilutions of the tested protein and standard drugs for $2 \mathrm{~h}$, and then the viruses were added to Vero cells for another $2 \mathrm{~h}$. For the antireplicative effect, serial doses of silk protein and standard drugs were added after incubating Vero with viruses for $2 \mathrm{~h}$. After 3 days, MTT assay was used as described above to determine the percentage of cell lysis inhibition for each protein concentration to calculate the $\mathrm{IC}_{50}$ (using GraphPad InStat software) at which silk protein causes 50\% viral inhibition.

Moreover, quantitative real-time PCR (qPCR) was used to confirm the results of silk protein antiviral mode action obtained from the MTT assay. Following the seeding of Vero cells in 6-well culture plates for $24 \mathrm{~h}$, the above-mentioned experiments were repeated using $100 \mu \mathrm{g} / \mathrm{mL}$ and $10 \mu \mathrm{g} / \mathrm{mL}$ of silk protein against ADV7 and HSV-1, respectively, and compared to the standard drugs with the same concentrations. After $72 \mathrm{~h}$ incubation in $\mathrm{CO} 2$, the untreated and treated infected Vero cells, in each well, were collected for total DNA extraction using Qiagen extraction kit. TaqMan-based real-time PCRs (CFX, BIO RAD) were performed in accordance with [36,37]. The ADV7 qPCR primers were $5^{\prime}-$ GAGGAGCCAGATATTGATATGGAATT- ${ }^{\prime}$ and $5^{\prime}$-AATTGACATTTTCCGTGTAAAGCA$3^{\prime}$ with the probe $5^{\prime}$-6-carboxyfluorescein (FAM)-AAGCTGCTGACGCTTTTTCGCCTGA-6carboxytetramethylrhodamine (TAMRA)-3' ${ }^{\prime}$. For HSV-1 qPCR, primers were $5^{\prime}$-CATCACCG ACCCGGAGAGGGAC- $3^{\prime}$ and $5^{\prime}$-GGGCCAGGCGCTTGTTGGTGTA- $3^{\prime}$ and the probe was $5^{\prime}$-FAM-CCGCCGAACTGAGCAGACACCCGCGC-6-TAMRA-3'. The reaction mixture contained Taq polymerase $(0.05 \mathrm{U} / \mu \mathrm{L})$ and reaction buffer $(0.4 \mathrm{mM}$ of $\mathrm{dNTP}, 250 \mathrm{nM}$ probe, $400 \mathrm{nM}$ forward/reverse primers, and $4 \mathrm{mM} \mathrm{MgCl}_{2}$ ). PCR program started with $95^{\circ} \mathrm{C}$ for $15 \mathrm{~min}$, followed by 45 cycles of $95^{\circ} \mathrm{C}$ for $10 \mathrm{~s}, 55^{\circ} \mathrm{C}$ for $30 \mathrm{~s}$, and $72{ }^{\circ} \mathrm{C}$ for $20 \mathrm{~s}$. Viral load was estimated using standard curve.

2.5.2. Evaluation of the Inhibitory Impact of Silk Protein on DNA Polymerase Activity of ADV7 and HSV-1

The inhibitory effect of silk protein on viral DNA polymerase activity was determined using acid-precipitated radioactivity. The reaction mixture of ADV polymerase consisted of $25 \mathrm{mM}$ Tris- $\mathrm{HCl} \mathrm{pH} \mathrm{7.8,} 7 \mathrm{mM} \mathrm{MgCl}, 1 \mu \mathrm{g}$ aphidicolin, $10 \mathrm{mM}$ DTT, activated DNA, and $40 \mu \mathrm{M}$ deoxynucleotides with $1 \mu$ Ci radiolabeled [ $\alpha{ }^{32} \mathrm{P}$ ]dATP [38]. Meanwhile, the reaction mixture of $\mathrm{HSV}$ polymerase contained $50 \mathrm{mM}$ Tris- $\mathrm{HCl} \mathrm{pH} 8,0.5 \mu \mathrm{g} / \mathrm{mL}$ albumin, $100 \mathrm{mM}$ ammonium sulfate, $8 \mathrm{mM} \mathrm{MgCl} 2,0.5 \mathrm{mM}$ DTT, and $100 \mu \mathrm{M}$ deoxynucleotides with $1 \mu \mathrm{Ci}$ radiolabeled $\left[{ }^{3} \mathrm{H}\right.$-dTTP] $[39,40]$. The above-mentioned mixtures of ADV7 and HSV-1 were incubated with serial concentrations of silk protein for 30 and $60 \mathrm{~min}$, respectively. After reaction termination by acid precipitation, radioactivity was measured using a scintillation counter. 


\subsubsection{The Antiviral Activity of Silk Protein against HCV}

The inhibitory effect of silk protein on HCV in the isolated PBMCs of healthy donors was recorded. A nontoxic concentration of silk protein was simultaneously incubated with the virus (sterile filtered infected serum) for $90 \mathrm{~min}$. Then, cells were infected with $100 \mu \mathrm{L}$ of the cotreated virus for $72 \mathrm{~h}$ at $37^{\circ} \mathrm{C}$ and $5 \% \mathrm{CO} 2$. At the end of incubation, the infected cells were washed three times with $1 \mathrm{~mL}$ of PBS, and the total RNA was extracted using Qiagen Kit. The positive control of the infected untreated cells and the negative control of uninfected cells were included in the experiment.

\subsubsection{Quantification of HCV Genomic and Antigenomic RNA Strands Using RT-PCR}

To quantify HCV genomic and antigenomic RNA strands (minus strand), reverse transcription nested PCR was carried out as described previously and with minor changes [31]. Briefly, the reaction was carried out in $25 \mu \mathrm{L}$ with $20 \mathrm{U}$ of reverse transcriptase (Clontech, Mountain View, CA, USA) with $400 \mathrm{ng}$ of the total extracted PBMC RNA, $40 \mathrm{U}$ of RNAsin (Clontech, Mountain View, CA, USA), dNTP (Promega, Madison, WI, USA, at final concentration of $0.2 \mathrm{mmol} / \mathrm{L}$ ) and the reverse primer $1 \mathrm{CH}$ (for plus strand, $50 \mathrm{pmol}$ ) or forward primer $2 \mathrm{CH}$ (for minus strand, $50 \mathrm{pmol}$ ). The reaction was developed for $60 \mathrm{~min}$ at $42{ }^{\circ} \mathrm{C}$ and then denatured for $10 \mathrm{~min}$ at $98^{\circ} \mathrm{C}$. The amplification of highly conserved $5^{\prime}$-UTR sequences was completed using two PCR rounds (with two pairs of nested primers). The first-round amplification was conducted in $50 \mu \mathrm{L}$ reaction mixture having $2 \mathrm{CH}$ forward primer and P2 reverse primer (50 pmol from each), as well as dNTPs $(0.2 \mathrm{mmol} / \mathrm{L})$. RT reaction mixture $(10 \mu \mathrm{L})$ was used as a template with $2 \mathrm{U}$ of Taq DNA polymerase (Promega, Madison, WI, USA). The thermal cycling protocol was as follows: $94{ }^{\circ} \mathrm{C}$ for $1 \mathrm{~min}, 55{ }^{\circ} \mathrm{C}$ for $1 \mathrm{~min}$, and $1 \mathrm{~min}$ at $72{ }^{\circ} \mathrm{C}$ for 30 cycles. The second amplification cycle was similar to the first one, except for use of the nested reverse primer D2 and forward primer F2 (50 pmol). Primer sequences for the $5^{\prime} \mathrm{HCV}$ noncoding (NC) region amplification were as follows: $1 \mathrm{CH}$ : $5^{\prime}$-ggtgcacggtctacgagacctc- $3^{\prime}, 2 \mathrm{CH}: 5^{\prime}$-aactactgtcttcacgcagaa- $3^{\prime}, \mathrm{P} 2$ : $5^{\prime}$-tgctcatggtgcacggtcta-3', D2: $5^{\prime}$-actcggctagcagtctcgcg- $3^{\prime}$, and F2: $5^{\prime}$-gtgcagcctccaggaccc- $3^{\prime}$. To overcome the false detection of negative-strand HCV RNA and known variations in PCR competence, specific control assays and rigorous standardization of the reaction were completed: (1) cDNA was synthesized without RNA templates to avoid product contamination, (2) cDNA synthesis was synthesized without RTase to avoid Taq polymerase RTase activity, and (3) cDNA synthesis and PCR step were completed without any reverse or forward primers to avoid the contamination from mixed primers. In addition, cDNA synthesis was conducted using one primer followed by heat inactivation of RTase activity at $95{ }^{\circ} \mathrm{C}$ for $1 \mathrm{~h}$, in an effort to reduce the false presence of negative strands before the addition of the second primer. Finally, the RT-PCR was conducted using the final PCR product based on the SYBR Green I dye and LightCycler fluorimeter [41]. An external standard curve was done using 10-fold serial dilutions of a modified synthetic HCV 5' NC RNA [42].

\subsubsection{Quantification of the Induced ROS Using Oxidized DCFDA and Flow Cytometry}

ROS and oxidative damage are assumed to have a vital role in many human diseases. Using a cell-permeable fluorescent and chemiluminescent probe, $2^{\prime}-7^{\prime}$-dichlorodihydrofluorescein diacetate (DCFH-DA), we quantified the induced ROS in HCV-infected and treated cells using flow cytometry [43]. Briefly, after cellular treatment with the nontoxic dose of silk protein, all silk-protein-treated, $\mathrm{HCV}$-infected, and control PBMCs were incubated with DCFH-DA at a final concentration of $10 \mu \mathrm{M}$ for $30 \mathrm{~min}$ at $37^{\circ} \mathrm{C}$ and $5 \% \mathrm{CO}$. After incubation, cells were washed with prewarmed PBS and suspended in FAC buffer solution. The intensity of fluorescence was quantified by flow cytometry (Partec $\mathrm{GmbH}$, Germany), and the sample redox state was monitored by checking the increase in fluorescence that could be measured at $530 \mathrm{~nm}$ when the sample is excited at $485 \mathrm{~nm}$. 


\subsection{Protein Modeling and Validation}

Based on our previous data $[10,29]$, there is a great similarity between the Bombyx mori silk protein and the Bacillus silk protein. The analysis of the amino acid constituents showed that the block protein is rich in Ala-Pro-Gly, while the molecular weight (Mwt) of fibroin protein $\mathrm{H}$-chain was around $400 \mathrm{kDa}$, which exceeded that of the natural silk of Bombyx mori [44]. The bacterial silk-like nanofibers gave an adequate and uniform ribbonshaped structure with an average nanofiber diameter of around $110 \mathrm{~nm}$. Meanwhile, the block silk-like protein exhibited high thermal degradation monitored at $140-373{ }^{\circ} \mathrm{C}$, which is close to that of natural silkworms like Bombyx mori [45]. In our recently published work [30], the fibroin $\mathrm{H}$-chain exhibited a band at $\sim 400 \mathrm{kDa}$, while the fibroin L-chain exhibited a band at $\sim 35 \mathrm{kDa}$ and P25 proteins exhibited a band at $\sim 30 \mathrm{kDa}$. However, sericin proteins exhibited bands at 95,66, 16, and $6.5 \mathrm{kDa}$. The Bombyx mori silk fibroin P25 protein and sericin $1 \mathrm{~A}^{\prime}$ were used in the current study for the docking analysis due to the availability of their full sequences in the NCBI database. In addition, the Mwt of these proteins is similar to those of our bacterial silk proteins. Therefore, the current study used Bombyx mori silk fibroin p25 and sericin 1 $\mathrm{A}^{\prime}$ for the in silico analysis due to the availability of their full sequences in the NCBI database. The Protein Data Bank (PDB, Long Island, NY, USA, https: / / www.rcsb.org/ (accessed on 6 October 2021) was used to derive the 3D structures of HCV-NS5B (PDB: 3FQK, 576 res, chain A and B) and HSV1 DNA polymerase (PDB: 2GV9, 1193 res, chain A and B). However, the PDB of the unavailable 3D structures of silk fibroin, silk sericin, and human ADV7 DNA polymerase were generated by the SwissModel protein-modeling server (https: / / swissmodel.expasy.org/ (accessed on 13 October 2021) [46]. The amino acid sequences of silk fibroin (Accession: AAL83649, 262 amino acids), sericin 1A' (Accession: BAD00699, 722 amino acids), and ADV7DNA polymerase (Accession: ASK85767, 1193 amino acids) were retrieved from the NCBI protein database and then submitted to the Swiss-Model for analysis. The validation of the generated structural models was done by the PROCHEK Ramachandran plot $[47,48]$. The theoretical molecular weight values of the two Bombyx mori silk protein subunits were predicted from the protein amino acids by the EXPASY server (https://web.expasy.org/compute_pi/ (accessed on 14 October 2021) [49] to compare them with those obtained from the Bacillus strain.

\subsection{Molecular Docking Analysis}

The predicted mechanism of the silk sericin and silk fibroin inhibitory impact on the activity of HCV-NS5B and the DNA polymerase of HSV1 and ADV7 was assessed using molecular docking. The docking of the highest C-score proposed 3D structure models of silk sericin and silk fibroin, individually with each of the studied viral polymerases, was established by the GRAMM-X Protein-Protein Docking Server (http: / / vakser.compbio.ku. edu/resources/gramm/grammx / (accessed on 14 October 2021) [50]. Then, the binding pocket atoms of the created docked structural complexes were visualized and analyzed using the Discovery Studio 2020 Client program (v20.1.0.19295, Dassault Systèmes, VélizyVillacoublay, France).

\subsection{Assessment of the Binding Affinity in the Docked Complexes}

The PDBePISA (Proteins, Interfaces, Structures, and Assemblies) website (https:/ / www.ebi.ac.uk/msd-srv/prot_int/pistart.html (accessed on 15 October 2021) [51] was used to analyze the interface of the docked complexes. The numbers of interface residues and hydrogen bonds, along with the change in Gibbs free energy $(\Delta G$, solvation free energy) gained upon interface formation, are provided by this platform. The $\Delta \mathrm{G}$ value indicates the docked complex's binding affinity.

\subsection{Active Site Prediction}

The PDBsum web-based database (http://www.ebi.ac.uk/pdbsum (accessed on 19 October 2021) [48] was used in the current study to retrieve the active site residues of the HCV and HSV1 polymerases. The PDB IDs of these viral enzymes were required 
by this website; hence, it provides structural data on PDB database entries. However, the active site residues of ADV7 polymerase, which has no PDB ID, were predicted using the GASS-WEB server (https:/ / gass.unifei.edu.br/ (accessed on 23 October 2021) [52].

\subsection{Statistical Analysis}

All data are expressed as mean \pm standard error of the mean (SEM). The unpaired two-tailed Student's $t$-test of SPSS 16.0 was used. Statistical differences were expressed as $p$-value $<0.05^{*},<0.001^{* *},<0.0001^{* * *}$.

\section{Results}

\subsection{Cytotoxicity Assay}

Cytotoxicity assay was used to quantify both $\mathrm{IC}_{50}$ and nontoxic dose of silk protein on PBMCs and Vero cells using MTT assay protocol. The obtained results indicated that the nontoxic dose $\left(\mathrm{EC}_{100}\right)$ of silk protein on PBMCs and Vero cells reached $100 \mu \mathrm{g} / \mathrm{mL}$ with $\mathrm{IC}_{50}$ determined to be 460 and $743.3 \mu \mathrm{g} / \mathrm{mL}$, respectively. So, we selected a $100 \mu \mathrm{g} / \mathrm{mL}$ dose for completion of the antiviral assay (Figure 1). The recorded safe doses of silk protein, ribavirin, and acyclovir on Vero cells were 1000, 284.3, and $266.1 \mu \mathrm{g} / \mathrm{mL}$, respectively.
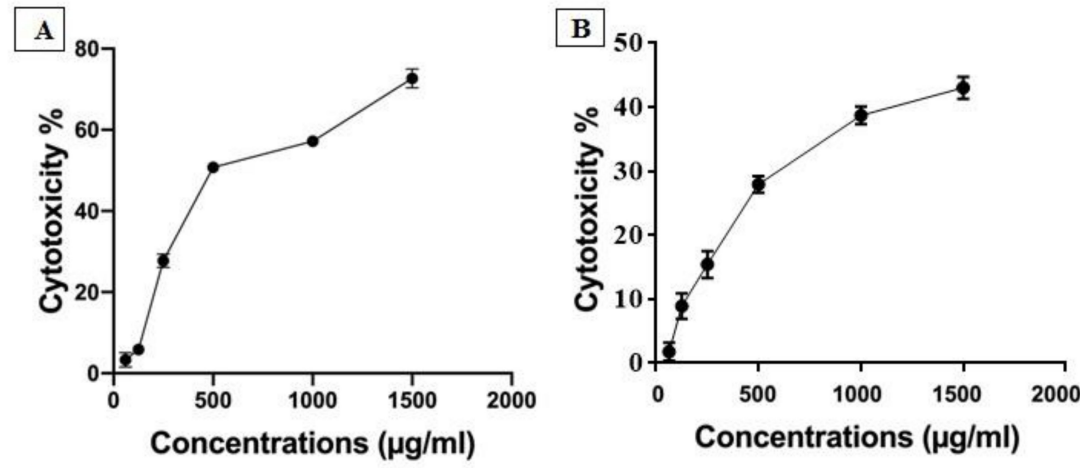

Figure 1. The safety patterns of silk protein on PBMCs (A) and Vero cells (B); different concentrations of silk protein (from 1500 to $62.5 \mu \mathrm{g} / \mathrm{mL}$ ) were tested on PBMCs to detect the nontoxic dose and $\mathrm{IC}_{50}$ value of silk protein.

\subsection{Antiviral Assays}

\subsubsection{Antiviral Assays on ADV7 and HSV1}

The antiviral mode of silk protein was investigated, at $100 \mathrm{TCID}_{50}\left(10^{-4}\right.$ and $10^{-3}$ of ADV7 and HSV-1, respectively), by quantifying the percentages of cell lysis inhibition and viral elimination using MTT and qPCR, respectively. This was achieved by preincubating the tested proteins with viruses before application to host cells (direct virucidal), pretreatment of host cells before adding viruses (antiadsorption), and addition after infection of host cells (antireplicative). Figure 2 illustrates that silk protein inhibited cell lysis in a dose-dependent manner. From these curves (Figure 2), $\mathrm{IC}_{50}$ values, representing the concentration at which $50 \%$ inhibition of cell lysis occurs, were calculated for each antiviral mode, and the lowest value refers to the most effective action mode(s) of this protein for combating ADV7 and HSV-1. The estimated $\mathrm{IC}_{50}$ values of silk protein for ADV7 inactivation were $46.4 \pm 0.5 \mu \mathrm{g} / \mathrm{mL}, 222.4 \pm 1.0 \mu \mathrm{g} / \mathrm{mL}$, and $109.2 \pm 2.1 \mu \mathrm{g} / \mathrm{mL}$ by direct virucidal, antiadsorption, and antireplicative modes of action, respectively. The values of $\mathrm{IC}_{50}$ for HSV-1 inactivation were $4.1 \pm 0.7 \mu \mathrm{g} / \mathrm{mL}, 12.5 \pm 0.1 \mu \mathrm{g} / \mathrm{mL}$, and $9.8 \pm 0.3 \mu \mathrm{g} / \mathrm{mL}$ by direct virucidal, antiadsorption, and antireplicative modes of action, respectively. These $\mathrm{IC}_{50}$ values and the highest percentage of cell lysis inhibition indicate that silk protein can inhibit virus-mediated cell lysis mainly via a direct virucidal effect with the lowest antiadsorption effect on both viruses. This protein exhibited a comparable antireplicative effect on both viruses. Standard drugs (ribavirin and acyclovir) only exhibited antireplicative effects with $\mathrm{IC}_{50}$ equivalent to $48.9 \pm 1.6 \mu \mathrm{g} / \mathrm{mL}$ and $30.9 \pm 0.7 \mu \mathrm{g} / \mathrm{mL}$, respectively, but $\mathrm{IC}_{50}$ 
values for other effects could not be determined because their maximum safe concentration did not reach 50\%. Accordingly, the anti-ADV and anti-HSV efficacy of silk protein is mainly achieved by direct virucidal and antireplicative manner, respectively. Therefore, these modes were selected for the following evaluation of its antiviral activity using more specific parameters.

A

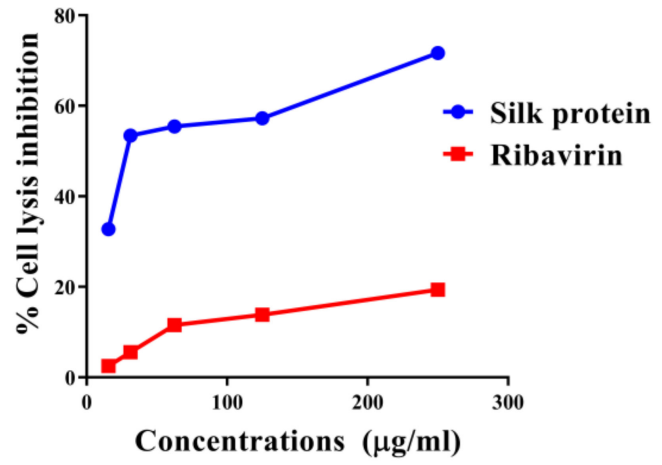

B

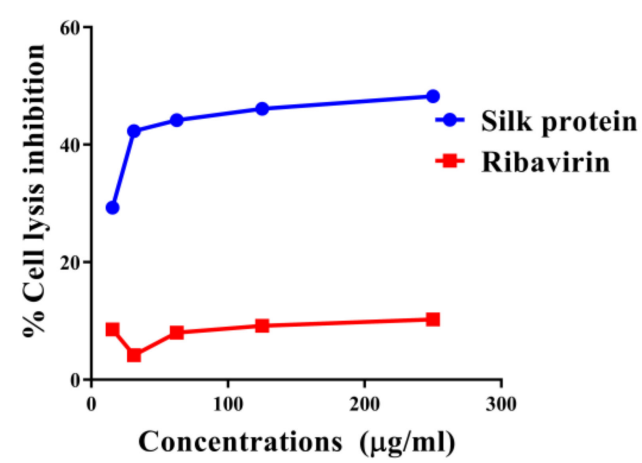

C

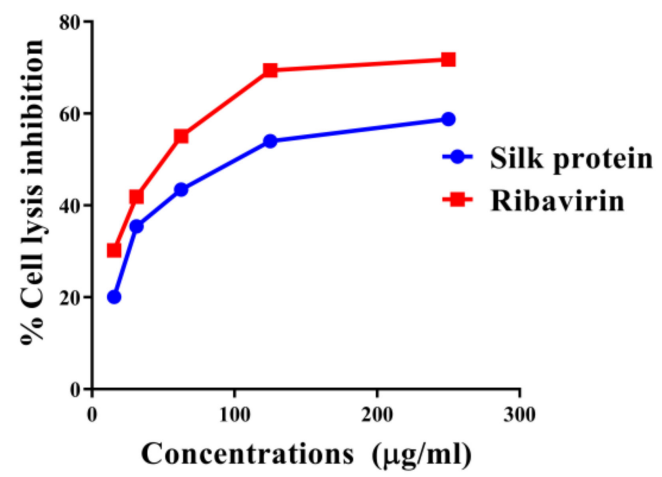

D

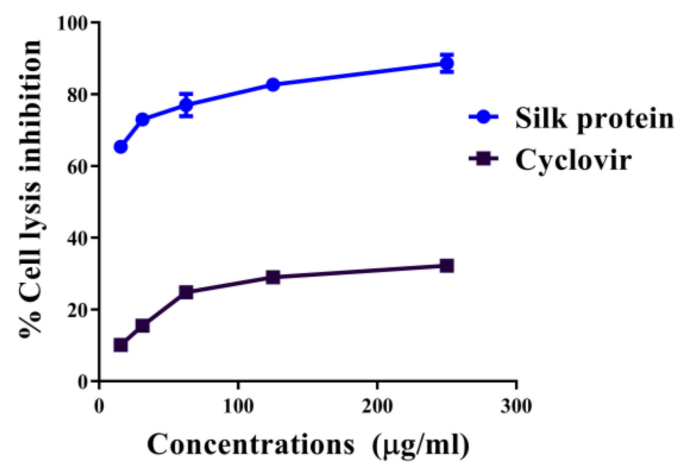

$\mathbf{E}$

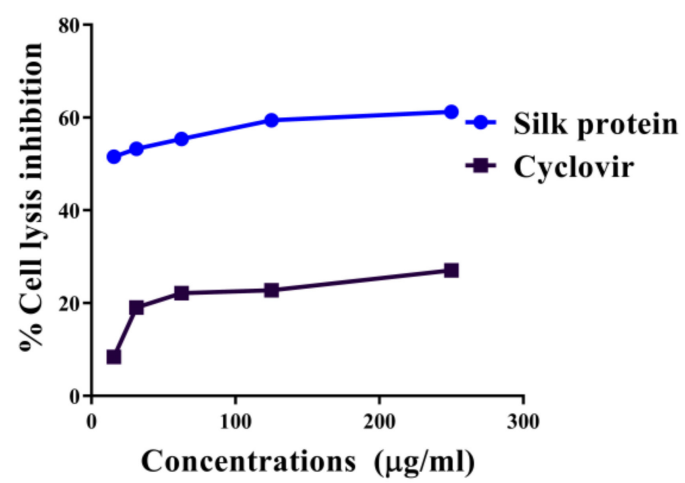

F

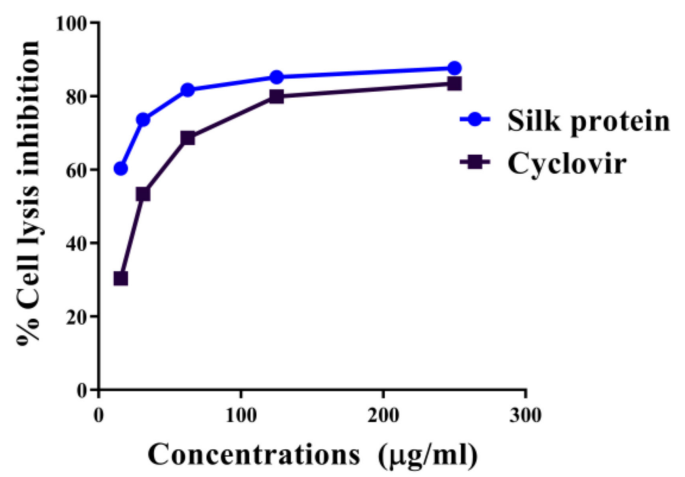

Figure 2. Percentage lysis inhibition of adenovirus (ADV7)- and herpes simplex virus (HSV-1)infected Vero cells after treatment with silk protein with modes of action illustrated. (A) Direct virucidal, (B) antiadsorption, and (C) antireplication effects of silk protein against ADV7 in comparison with standard drug (ribavirin) in the term of \% cell lysis inhibition. (D) Direct virucidal, (E) antiadsorption, and (F) antireplication activity of silk protein against HSV1 in comparison with standard drug (acyclovir) in the term of \% cell lysis inhibition. All data are expressed as mean \pm SEM. 
Data of qPCR for cellular virus contents supported MTT results of cell lysis inhibition. As shown in Figure 3, this protein eliminated $85.7 \%$ and $89.9 \%$ of ADV7 and HSV1, respectively, by direct virucidal activity, while its antireplication effect caused viral elimination by $63.2 \%$ and $77.5 \%$, respectively. On the other hand, standard drugs achieved viral elimination $(77.9 \%$ and $62.9 \%$, respectively) only via their antireplicative effect. Figure 3 also shows that silk protein had significantly stronger direct ADV7 and HSV1 virucidal effect and anti-HSV1 replicative potential than standard drugs. Meanwhile, no significant difference in anti-ADV7 replicative activity was recorded between silk protein and ribavirin.
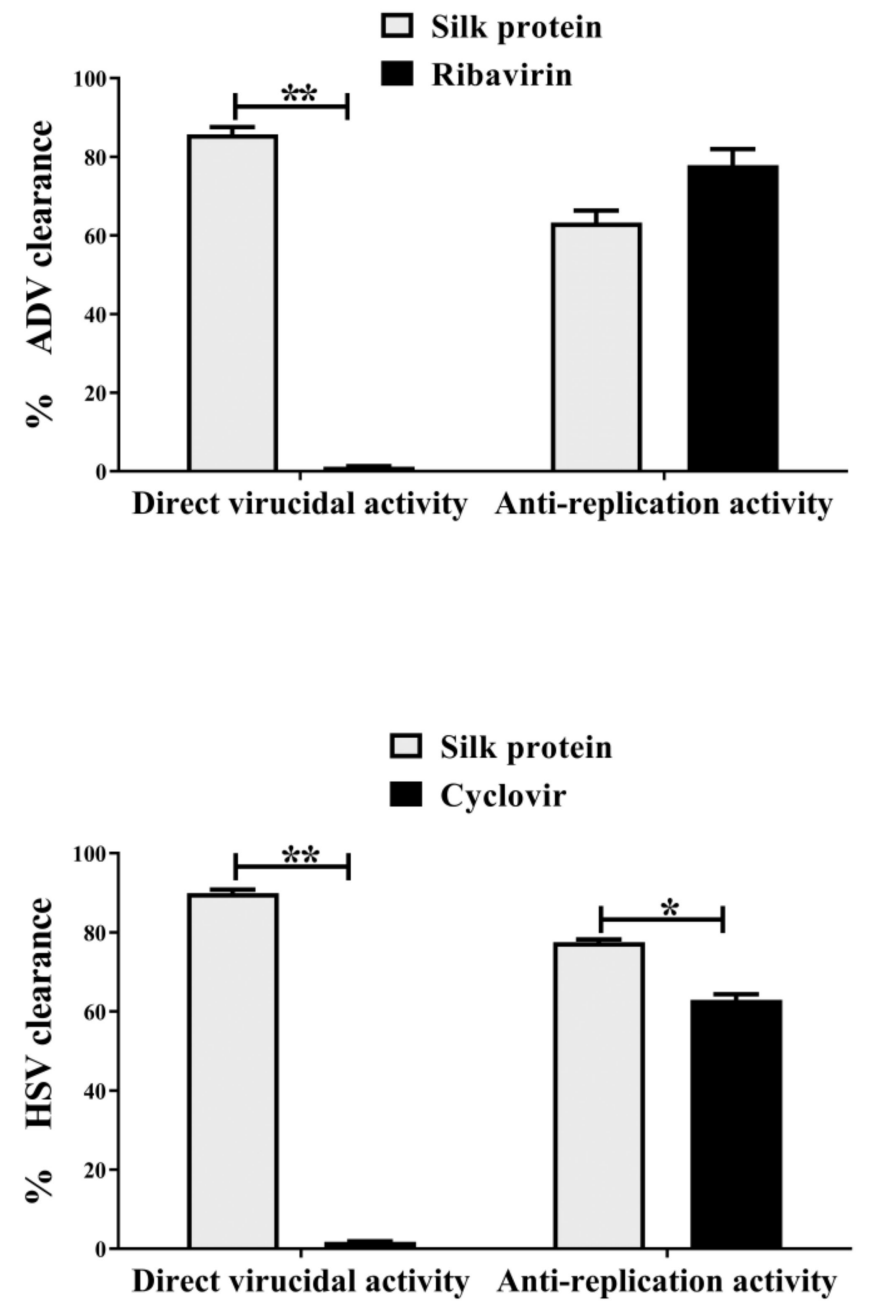

Figure 3. Percentage of adenovirus (ADV7) and herpes simplex virus (HSV-1) eliminated by direct virucidal and antireplication potentials of silk protein in comparison with standard drugs (ribavirin and acyclovir). All data are expressed as mean \pm SEM and considered significantly different at $p<0.05^{*}, p<0.005^{* *}$.

The antireplicative activity of silk protein was further assessed by estimating the $\mathrm{IC}_{50}$ for inhibition of viral DNA polymerases (Figure 4). It was found that silk protein can inhibit these viral polymerases at $164.1 \pm 11.1 \mu \mathrm{g} / \mathrm{mL}$ and $11.8 \pm 0.6 \mu \mathrm{g} / \mathrm{mL}$ for ADV7 and HSV1, respectively, with no significant difference when compared to standard drugs (Figure 4).

\subsubsection{Anti-HCV Activity of Silk Protein}

The ability of silk protein to inhibit HCV replication on PBMCs was quantified using qPCR. The obtained results indicated that silk protein at $100 \mu \mathrm{g} / \mathrm{mL}$ showed the ability to inhibit HCV replication on the PBMC model by $66.2 \%$ via reducing the viral load from $1.36 \times 10^{6}$ to $0.9 \times 10^{5}$ copies $/ \mathrm{mL}$ (Figure 5 and Table 1 ). 


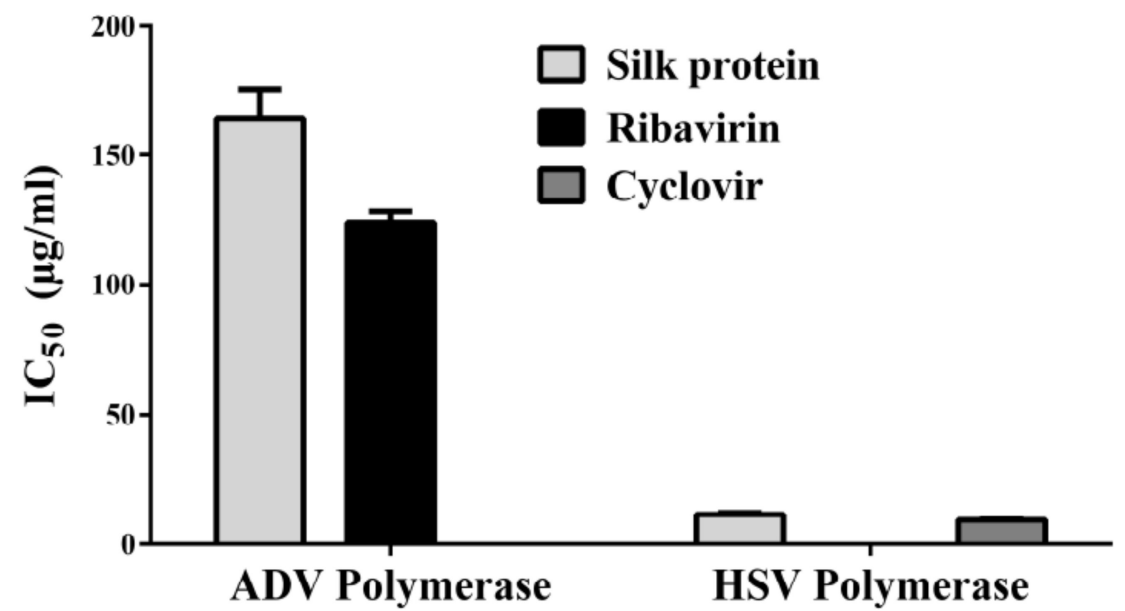

Figure 4. $\mathrm{IC}_{50}$ values of silk protein for inhibiting DNA polymerases of ADV and HSV. All data are expressed as mean \pm SEM.

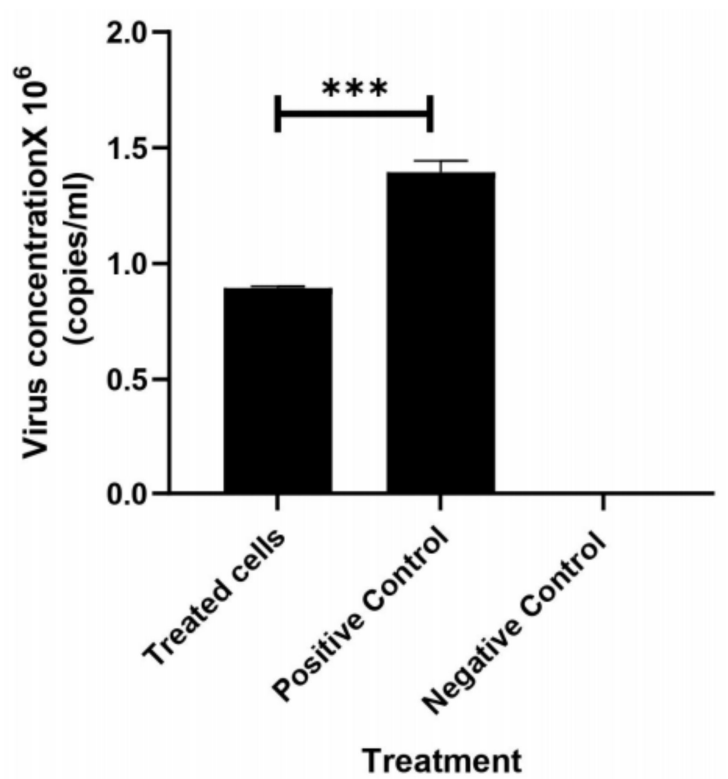

Figure 5. Quantification of HCV viral replication inhibition in PBMCs using RT-qPCR. All data are expressed as mean \pm SEM and considered significantly different at $p<0.0005 * * *$.

Table 1. Determination of HCV viral count in PBCs using RT-qPCR.

\begin{tabular}{ccccc}
\hline Samples & Fluor & Cq & Virus Conc. (Copies/mL) & Inhibition\% \\
\hline Treated cells & SYBR & 23.89 & $0.9 \times 10^{5}$ & 66.2 \\
\hline Positive control & SYBR & 28.33 & $1.36 \times 10^{6}$ & 0.0 \\
\hline Negative control & SYBR & 4.69 & - & - \\
\hline
\end{tabular}

\subsubsection{Quantification of the Induced ROS Using Flow Cytometry in HCV-Infected Model}

The induced cellular ROS in PBMCs after HCV infection and treatment were quantified using flow cytometry (Figure 6). The obtained results indicated a great induction of cellular ROS in PBMCs after HCV infection (87.9) compared with the uninfected cells (9.5). After treatment, silk protein dramatically reduced the induced ROS from 87.9 to 44.5 with $50.6 \%$ inhibition (Figure 7). It is also worth mentioning that silk protein did not induce a significant ROS induction (6.6) in PBMCs compared with the negative untreated cells. 

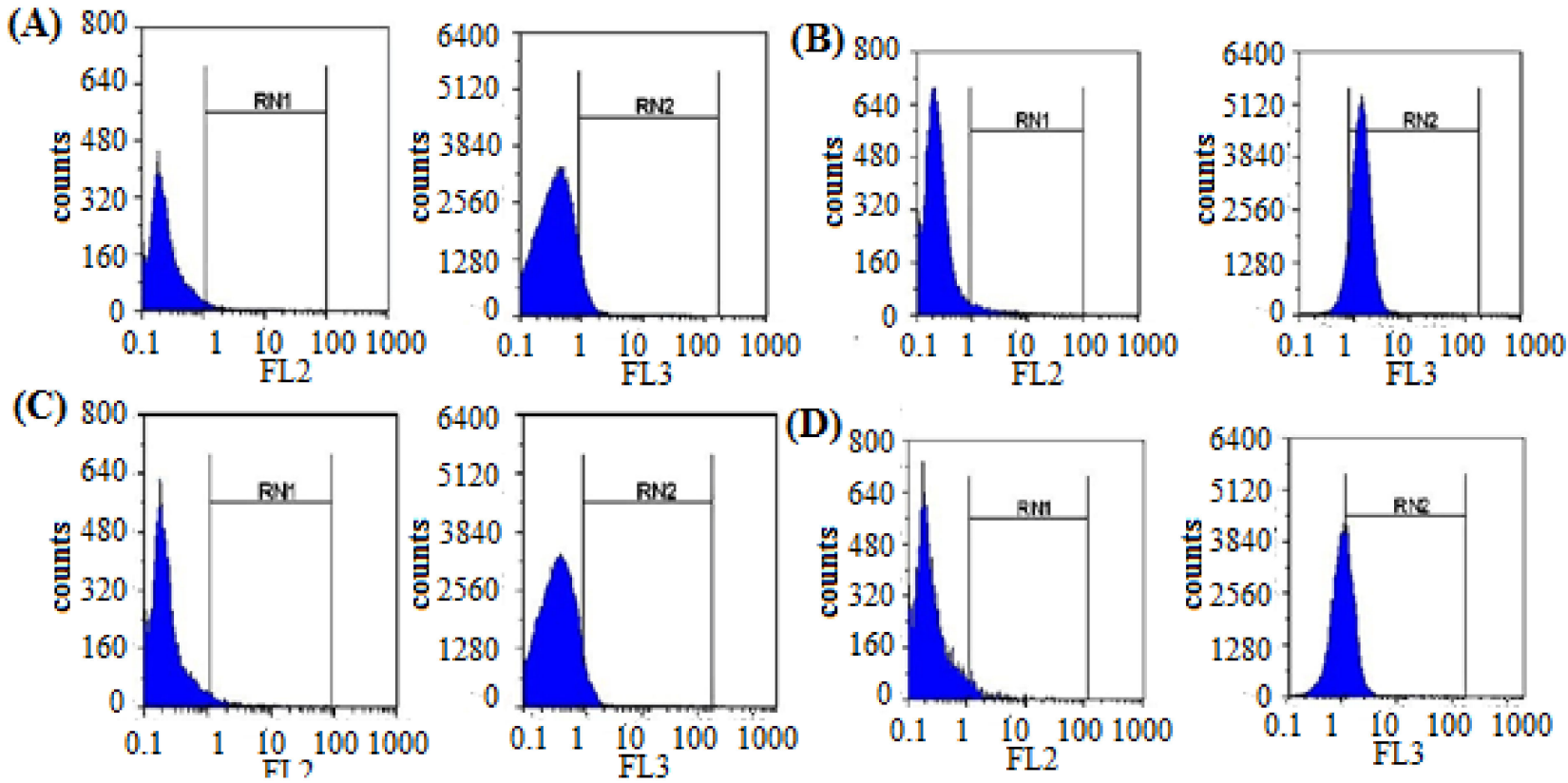

Figure 6. The flow cytometry analysis of the cellular induced ROS in untreated control cells (A), positive control HCV infected cells (B), silk-protein-treated cells (C), and silk-protein-treated HCVinfected cells (D). RN1 is the gating region for parameter number 1 using red laser and RN2 is the gating region for parameter number 1 using blue laser.

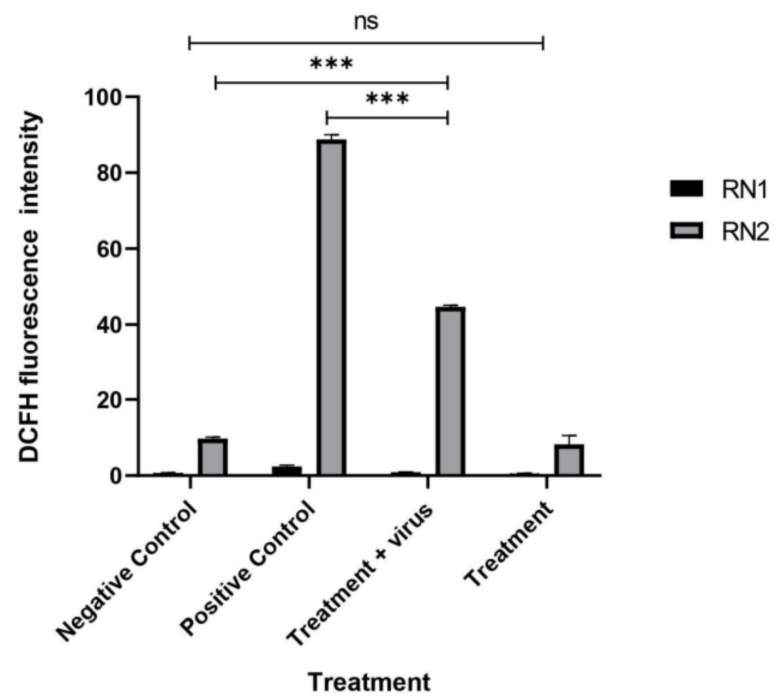

Figure 7. The fluorescence intensity in HCV-infected PBMC models after silk protein treatment. All data are expressed as mean \pm SEM and considered significantly different at $p<0.05^{*}, p<0.005^{* *}$, $p<0.0005^{* * *}$.

\subsubsection{D Predicted Structure Models}

The 3D structures of the two silk protein subunits and ADV7 polymerase were modeled by the Swiss-Model server. The protein sequences in Fast Adaptive Shrinkage Threshold Algorithm (FASTA) format were submitted to this online tool to supply the most accurate predictions for their structure. Model 1, with the highest quality and a good $\mathrm{C}$-score value, was established (Figure $8 \mathrm{~A}-\mathrm{C}$ ). The molecular weight values of the Bombyx mori silk fibroin and sericin $1 \mathrm{~A}^{\prime}$ were computed using the Expasy online server. The results showed a great similarity between them (27.6 and $69.9 \mathrm{kDa}$, respectively) and those obtained from Bacillus sp. (30 and $66 \mathrm{kDa}$, respectively) in our recently published work [10]. 
Therefore, these two types of Bombyx mori silk protein subunits were chosen here for the computational studies.

A
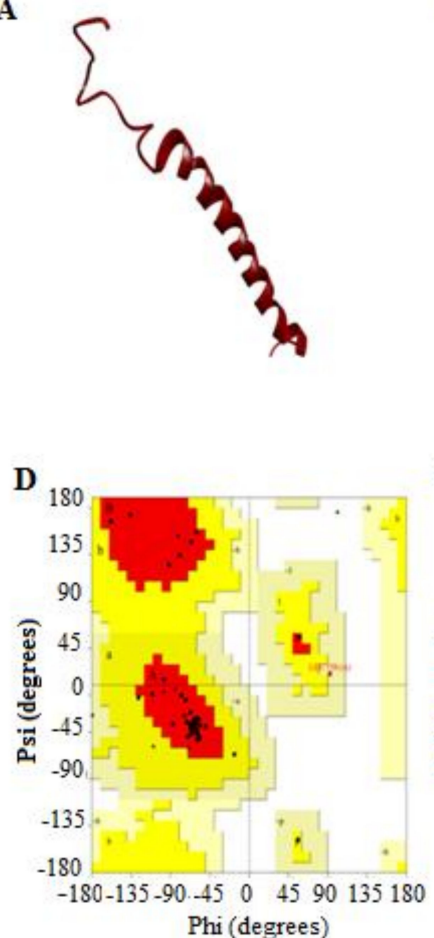

B

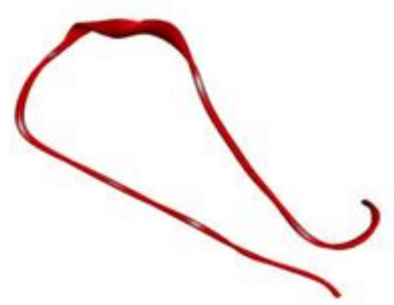

E

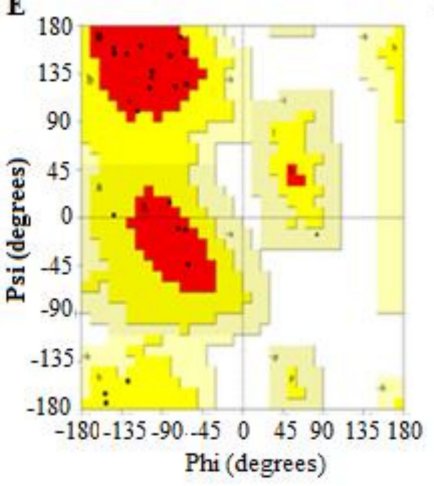

C

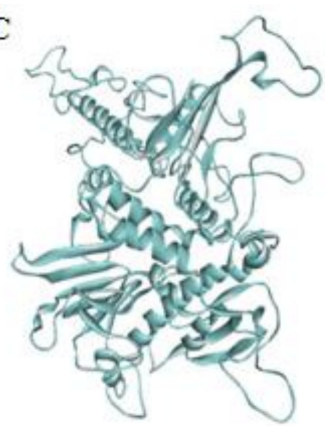

F

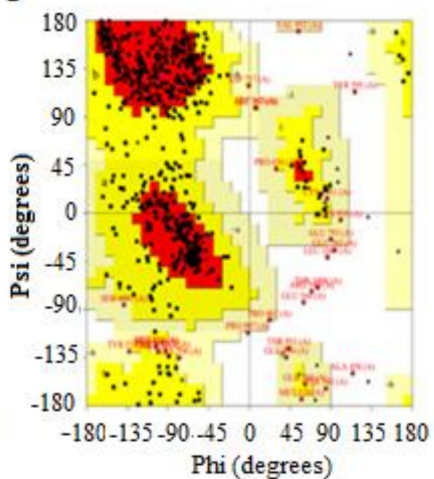

Figure 8. The 3D predicted structures of the silk protein subunits, fibroin and sericin, and ADV7 polymerase and their validation. (A-C) Backbone structure of silk fibroin, sericin, and ADV7 polymerase, respectively, as given by Swiss-Model protein-modeling server (https:/ / swissmodel.expasy.org/ (accessed on 13 October 2021). (D-F) Ramachandran plots of silk protein fibroin, sericin, and ADV7 polymerase, respectively.

The quality of the predicted structures was confirmed by the Ramachandran plot (Figure $8 \mathrm{D}-\mathrm{F})$, which analyzed psi $(\psi)$ and phi $(\mathrm{F})$ torsion angles of the structural backbone. The residues of the ADV7 polymerase 3D structure in the most favored, allowed, and disallowed regions were $74.7 \%, 24.0 \%$, and $1.3 \%$, respectively. For the 3D structure of silk fibroin, these values were $89.5 \%, 10.5 \%$, and $0 \%$, respectively. For the 3D structure of silk sericin, these values were $76.2 \%, 23.8 \%$, and $0 \%$, respectively. The overall G-factors (measurement of unusualness for main-chain dihedral angles and covalent forces) of the predicted models of ADV7 polymerase, fibroin, and sericin were $-0.41,-0.27$, and -0.31 , respectively. These results indicated that the dihedral angles, $\psi$ and $F$, in the selected model backbone were reasonably accurate.

\subsection{The Predicted Inhibitory Mechanism of Silk Fibroin and Sericin on ADV7, HCV, and HSV-1 Polymerases}

To predict the inhibitory mechanism of the silk protein on the polymerase activity of the target viruses, the silk fibroin or sericin was docked separately with the viral polymerase (Figures 9 and 10). Then, the docked complex was analyzed by the PDBePISA tool to explore the binding affinity, interface residues, and other details. The outcomes of PDBePISA showed that fibroin interacted with chain A of ADV7 polymerase (47 res, 6 hydrogen bonds) and both chains A and B of HCV (48 res, 4 hydrogen bonds) and HSV-1 (29 res, 3 hydrogen bonds) polymerases. Sericin bound to chain A of ADV7 polymerase (48 res, 7 hydrogen bonds), chain B of HCV polymerase (32 res, 11 hydrogen bonds), and chains $\mathrm{A}$ and B of HSV-1 polymerase (27 res, 4 hydrogen bonds). Furthermore, the binding affinity of fibroin and sericin to the studied polymerases was deduced from the predicted 
$\Delta \mathrm{G}$ values. These values were -23.0 (ADV7 polymerase), -11.2 ( $\mathrm{HCV}$ polymerase), and $-14.4 \mathrm{kcal} / \mathrm{mol}$ (HSV-1 polymerase) for fibroin and $-17.6,-10.5$, and -9.0 , respectively, for sericin. The $\Delta \mathrm{G} p$-value was also provided by the PDBePISA and indicated that the interface surface in the studied fibroin- or sericin-polymerase docked complexes was interactionspecific ( $p$-value < 0.5). The active site residues of ADV7, HCV, and HSV-1 polymerases were compared with the interface residues in the fibroin- or sericin-polymerase docked complexes. The results showed that either fibroin or sericin interacted with the active site residues of the examined viral polymerases, except for HCV polymerase, for which fibroin bound to R200A only (Figure 9B).
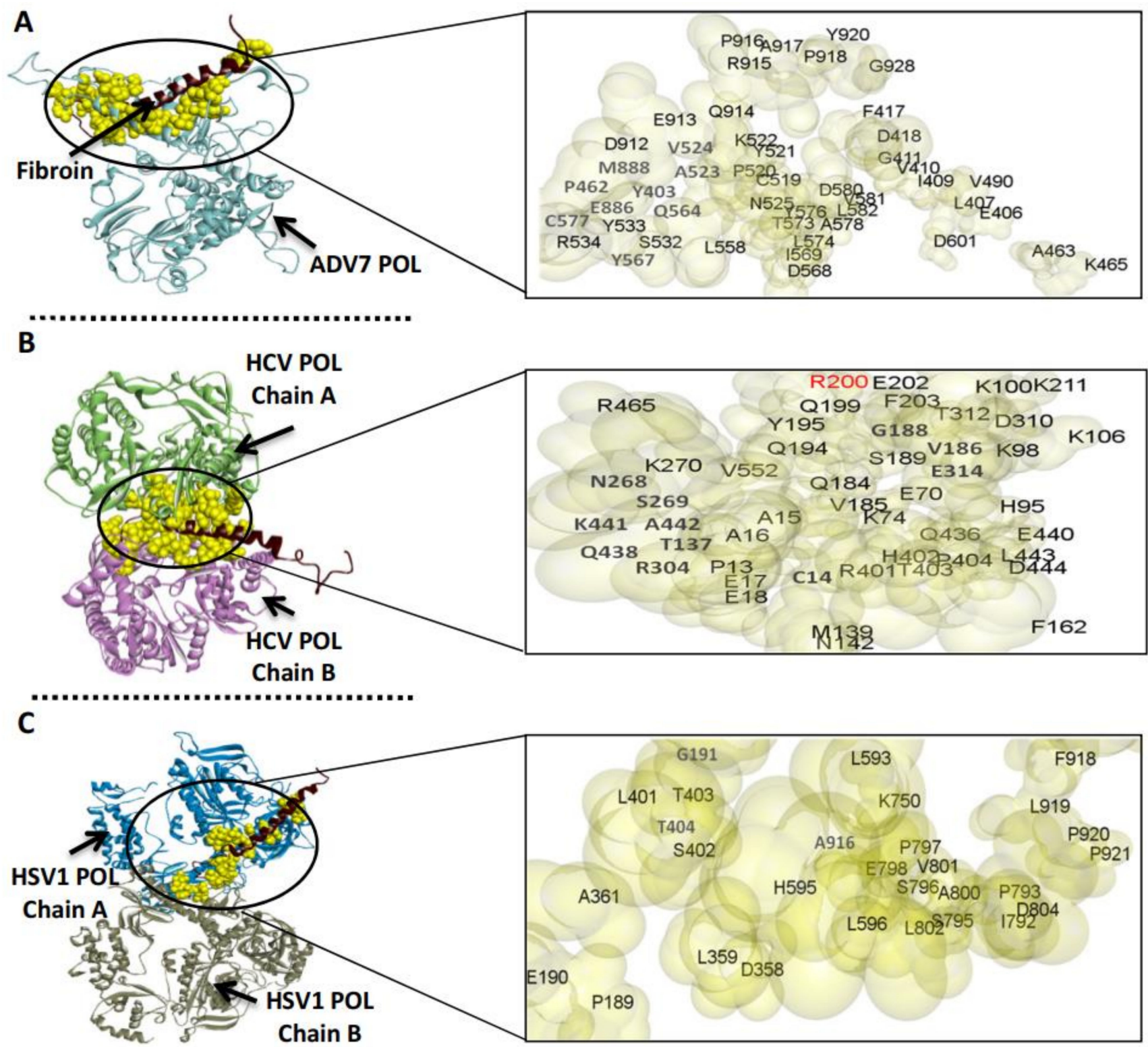

Figure 9. Molecular docking of ADV7, HCV, and HSV-1 polymerase (POL) and silk fibroin. (A-C) The docked complexes of ADV7 POL (shown in light blue), HCV POL (shown in light green "chain A" and purple "chain B"), and HSV-1 POL (shown in blue "chain A" and gray "chain B") with fibroin (shown in dark red), respectively, as provided by the GRAMM-X Protein-Protein Docking platform and visualized by Discovery Studio software. The interacting pocket residues of the docked complex are indicated by yellow space-filling spheres style, magnification of these regions shows the interface residues on the viral polymerase (shown in pale yellow-gray surface), and the red-colored residue represents the matched residue with the enzyme active site. 

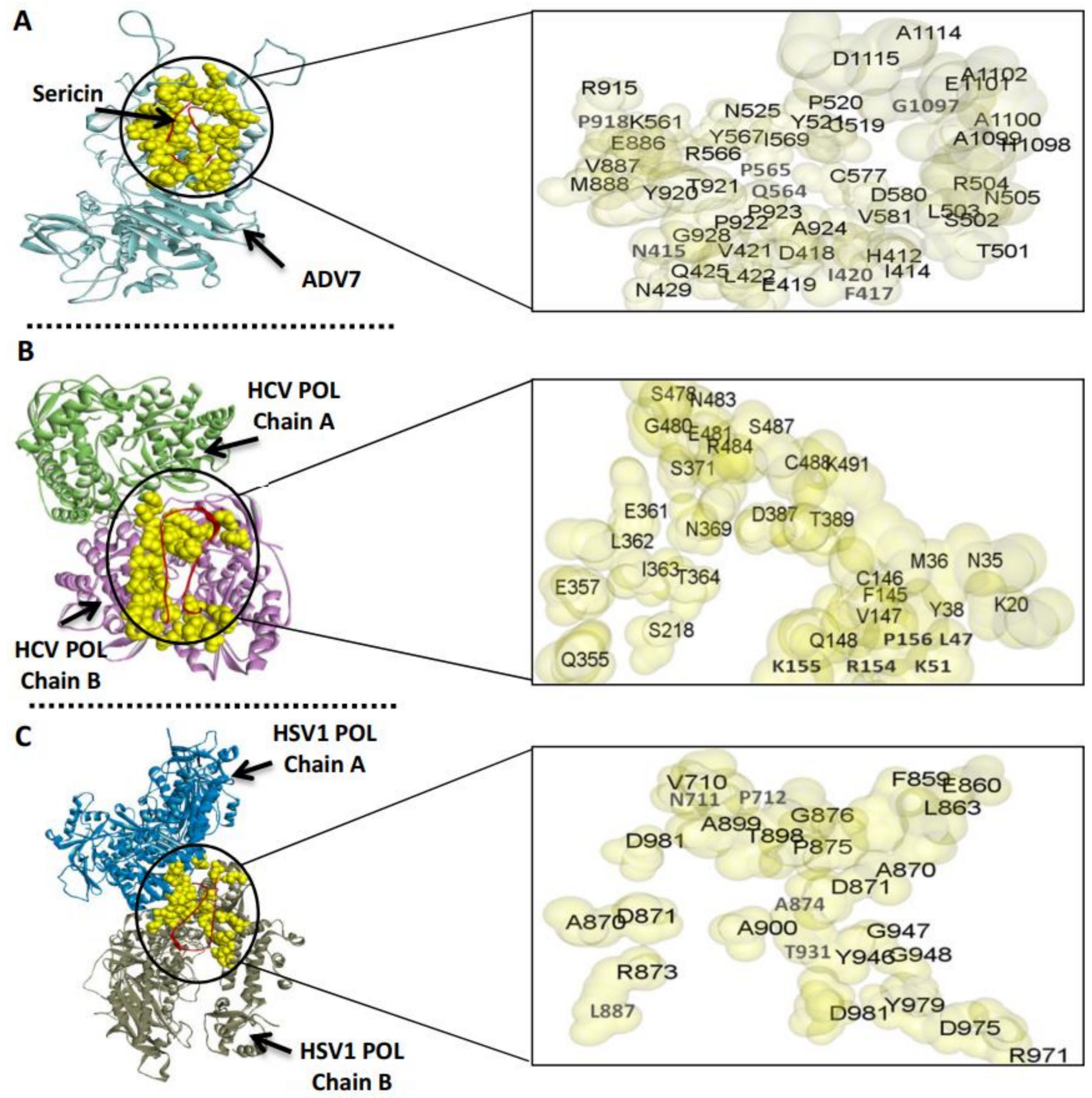

Figure 10. Molecular docking of ADV7, HCV, and HSV-1 polymerase (POL) and silk sericin. (A-C) The docked complexes of ADV7 POL (shown in light blue), HCV POL (shown in light green "chain $\mathrm{A}^{\prime}$ and purple "chain B"), and HSV1 POL (shown in blue "chain A" and gray "chain B") with sericin (shown in dark red), respectively, as provided by the GRAMM-X Protein-Protein Docking platform and visualized by Discovery Studio software. The interacting pocket residues of the docked complex are indicated by yellow space-filling spheres style, and magnification of these regions shows the interface residues on the viral polymerase (shown in pale yellow-gray surface).

\section{Discussion}

There are essential requirements for the discovery and exploration of novel natural agents against both RNA and DNA viruses. A variety of natural compounds derived from microorganisms and plants as medicinal products have been investigated for the management and control of numerous viral diseases. Silk is considered one of the most important natural fibrous proteins and is mainly obtained from animal origins, including silkworms and spiders. Therefore, the most popular studies in this field have focused 
on the production of polymeric silk proteins from animal origins or using genetically engineered bacteria [53-55]. We identified a previously isolated bacterial strain from petroleum oil origin called Bacillus sp. strain NE (MK231249) with the ability to form an exo-biopolymeric extract. Using molecular identification and exo-polymer chemical and physical characterizations, this bacterial exo-polymeric extract was identified as a bacterial silk-like protein [29]. In a previous study, El-Fakharany et al. revealed that the extracted sericin from bacterial silk was found to be like that isolated from animal origin, with potent biological activities, including antioxidant, anticancer, and antibacterial activities [10]. Silk proteins of animal origin have many biological and pharmacological properties, including antioxidant, antitumor, antimicrobial, and anti-inflammatory functions. The available studies on silk proteins show that these proteins may reduce the free radicals in the surrounding media and contamination by microbial pathogens such as bacteria and fungi. Therefore, silk proteins can be used in numerous applications, such as in the treatment of fabrics for medicinal uses and the preparation of wound healing gels. A particular coating of sericin on polyamide or polyester had been used as media for air filters, which were found to assist in sanitizing the contaminated air $[9,52,53]$. In the literature, there are several studies about the investigation of the antibacterial and antifungal activities of silk proteins, but reports on their antiviral properties are relatively rare. The present study, for the first time, was aimed to investigate the action of bacterial silk-like proteins against different types of viruses. For this purpose, the whole bacterial silk-like proteins were checked for their potential antiviral activity against HSV-1, ADV7, and HCV infectivity in Vero cells and PBMCs. The obtained results revealed that the bacterial silk-like proteins can display a direct virucidal effect on HSV-1 and ADV7, which might be through their amino acid structure and the action of secondary metabolites such as polyphenols and flavonoids [8]. In fact, the bacterial silk-like proteins were able to inhibit and neutralize the infection of HSV-1 and ADV7 upon entry into Vero cells with $\mathrm{IC}_{50}$ values of $4.1 \pm 0.7 \mu \mathrm{g} / \mathrm{mL}$ and $46.4 \pm 0.5 \mu \mathrm{g} / \mathrm{mL}$, respectively. At similar conditions, the $\mathrm{IC}_{50}$ values of adsorption inhibitory effect on HSV-1 and ADV7 were estimated to be $12.5 \pm 0.1 \mu \mathrm{g} / \mathrm{mL}$ and $222.4 \pm 1.0 \mu \mathrm{g} / \mathrm{mL}$, respectively. Furthermore, the bacterial silk-like proteins showed potent antireplication activities against HSV-1 and ADV7 with $\mathrm{IC}_{50}$ values of $9.8 \pm 0.3 \mu \mathrm{g} / \mathrm{mL}$ and $109.3 \pm 2.1 \mu \mathrm{g} / \mathrm{mL}$, respectively. Results of the present study indicated that the bacterial silk proteins had the ability to eliminate ADV7 and HSV-1 by direct virucidal activity determined to be $85.8 \%$ and $89.9 \%$, respectively, using qPCR and MTT methods. We showed that the antireplication effect of these proteins exhibited viral elimination of about $63.2 \%$ and $77.5 \%$, respectively. However, ribavirin and acyclovir exhibited an antireplicative effect determined to be $77.9 \%$ and $62.9 \%$, respectively. On the other hand, the bacterial silk proteins showed inhibitory mechanisms of viral polymerases with $\mathrm{IC}_{50}$ estimated to be $164.1 \pm 11.1 \mu \mathrm{g} / \mathrm{mL}$ and $11.8 \pm 0.6 \mu \mathrm{g} / \mathrm{mL}$ against ADV7 and HSV-1, respectively, similar to the inhibitory effect of the standard drugs.

For the anti-HCV inhibitory effect of bacterial silk proteins, the replication of HCV was inhibited by $66.2 \%$ inside infected PBMCs, as determined using RT-qPCR technique, at a concentration of $100 \mu \mathrm{g} / \mathrm{mL}$. Furthermore, the bacterial silk proteins showed a potent reduction in cellular ROS inside the HCV-infected PBMCs with an inhibition percentage of $50.6 \%$, as compared to untreated HCV-infected cells which showed ROS activity determined to be $87.9 \%$. The docking analysis revealed that silk fibroin and sericin can interact with ADV7, HSV-1, and HCV polymerases by hydrogen bonds and salt bridge interactions, and the interface surface in the obtained docked complexes is interaction-specific $\left(\Delta^{\mathrm{i}} \mathrm{G}\right.$ $p$-values < 0.5). From the $\Delta^{\mathrm{i}} \mathrm{G}$ values, we can deduce that the binding affinity of silk fibroin to ADV7 and HSV-1 polymerases was greater than that of silk sericin. Both silk proteins had nearly the same binding affinity to the HCV polymerase. The computational findings also demonstrated the inability of either silk fibroin or sericin to bind to the predicted active site residues of ADV7, HSV-1, or HCV polymerases. So, these viral polymerases can be inhibited by silk fibroin or sericin in an uncompetitive or noncompetitive manner [56]. This can be attributed to the distinctive capability of binding regions to be engaged in multiple interactions with various binding partners of bacterial silk proteins. One of the 
main possible mechanisms for this antiviral potential could be related to the relatively high cationic nature of the silk polymer, which enables it to bind to the infected host cells and block the viral particles from entry.

The biological activities of silk-like proteins are attributed to their unique composition of amino acids; in particular, their structures contain hydroxyl groups of serine and threonine, which chelate many essential elements like iron. In addition, silk sericin has many aromatic amino acids in its structure, which provide an electron-donating property, besides the action of secondary metabolites such as flavonoids and polyphenols [8,57]. Furthermore, alteration in $\mathrm{pH}$ of protein during the extraction process (e.g., using base or acid environment with heating) changes the ionization of amino acid, consequently producing sericin proteins with different lengths which contain large proportions of $\beta$-sheets, $\alpha$-helix, turns, and random coils [58]. Additionally, percentages of random coils and $\beta$-sheets reflect the amorphous nature or crystallinity of sericin protein, respectively [59]. Moreover, the bacterial silk-like protein was found to contain unique amino acids such as glycine and proline and contain aliphatic hydrophobic amino acids such as alanine, valine, leucine, and isoleucine with overall composition of 32\% [29]. The bacterial silk-like biopolymer can be developed into medicinally useful lead candidates for antiviral therapeutics and control.

\section{Conclusions}

The results obtained from the present study confirm that the bacterial silk-like proteins have potent antiviral activity against both DNA and RNA viruses. Considering the other biomedical properties and various biotechnological uses of bacterial silk-like proteins, our findings establish the further significance of these proteins as a biopharmaceutic candidate that may be incorporated with other potent drugs for delivery enhancement and achievable treatment. In vitro studies revealed that the bacterial silk-like proteins showed efficient antiviral activities using many molecular mechanisms with high safety on normal cells. Consequently, these results indicate that bacterial silk-like proteins can also be widely applied in controlling and managing viral infection and pandemics (especially in the control of COVID-19) alone or incorporated with other viral drugs. Furthermore, the demand for efficient antiviral drugs with high safety might prompt the consideration of the use of the bacterial silk proteins as a potent candidate in medicinal applications.

Author Contributions: E.M.E.-F.: Conceptualization, formal analysis, methodology, software, data curation, collected literature data, wrote and edited the manuscript. M.M.A.-S.: Conceptualization, formal analysis, methodology, software, data curation, collected literature data, wrote and edited the manuscript. N.H.H.: Conceptualization, formal analysis, methodology, software, data curation, collected literature data, wrote and edited the manuscript. N.M.E.-D.: Conceptualization, formal analysis, methodology, software, data curation, collected literature data, wrote and edited the manuscript. G.M.A.-E.: Conceptualization, formal analysis, methodology, software, data curation, collected literature data, wrote and edited the manuscript. S.Z.: Conceptualization, formal analysis, methodology, software, data curation, collected literature data, wrote and edited the manuscript. D.A.-E.-H.: Conceptualization, formal analysis, methodology, software, data curation, collected literature data, wrote and edited the manuscript. All authors have read and agreed to the published version of the manuscript.

Funding: This study did not receive any specific grant from funding agencies in the public, commercial, or not-for-profit sectors.

Institutional Review Board Statement: Not applicable.

Informed Consent Statement: This research did not include any animal experiments, and the protocols of blood sample collection were approved by the Research Ethical Committee at City of Scientific Research and Technological Applications (SRTA-City), Centre of Excellence for Drug Preclinical Studies (CE-DPS), Alexandria, Egypt, under international, national, and/or institutional guidelines. The blood samples were collected from hepatitis $C$ patient volunteers, and all volunteers provided written informed consent in conformity with our all guidelines. 
Data Availability Statement: The data presented in this study are available on request from the corresponding author.

Conflicts of Interest: The authors declare that there is no conflict of interest regarding the publication of this paper.

\section{References}

1. Zhang, W.; Jiang, X.; Bao, J.; Wang, Y.; Liu, H.; Tang, L. Exosomes in Pathogen Infections: A Bridge to Deliver Molecules and Link Functions. Front. Immunol. 2018, 9, 90. [CrossRef]

2. Saad, M.H.; Badierah, R.; Redwan, E.M.; El-Fakharany, E.M. A Comprehensive Insight into the Role of Exosomes in Viral Infection Dual Faces Bearing Different Functions. Pharmaceutics 2021, 13, 1405. [CrossRef] [PubMed]

3. Holland, C.; Numata, K.; Rnjak-Kovacina, J.; Seib, F.P. The Biomedical Use of Silk: Past, Present, Future. Adv. Health Mater. 2019 8, e1800465. [CrossRef]

4. Pereira, A.M.; Machado, R.; da Costa, A.; Ribeiro, A.; Collins, T.; Gomes, A.; Leonor, I.B.; Kaplan, D.L.; Reis, R.L.; Casal, M. Silk-based biomaterials functionalized with fibronectin type II promotes cell adhesion. Acta Biomater. 2017, 47, 50-59. [CrossRef]

5. Silva, V.R.; Ribani, M.; Gimenes, M.L.; Scheer, A.P. High Molecular Weight Sericin Obtained by High Temperature and Ultrafiltration Process. Procedia Eng. 2012, 42, 833-841. [CrossRef]

6. Zhaorigetu, S.; Sasaki, M.; Kato, N. Consumption of Sericin Suppresses Colon Oxidative Stress and Aberrant Crypt Foci in 1,2-Dimethylhydrazine-Treated Rats by Colon Undigested Sericin. J. Nutr. Sci. Vitaminol. 2007, 53, 297-300. [CrossRef] [PubMed]

7. Nuchadomrong, S.; Senakoon, W.; Sirimungkararat, S.; Senawong, T.; Kitikoon, P. Antibacterial and antioxidant activities of sericin powder from Eri Silkworm Cocoons Correlating to Degumming processes. Int. J. Wilk Silkmoth Silk 2008, 13, 69-78.

8. Kumar, J.P.; Mandal, B.B. Antioxidant potential of mulberry and non-mulberry silk sericin and its implications in biomedicine. Free. Radic. Biol. Med. 2017, 108, 803-818. [CrossRef] [PubMed]

9. Chanu, S.B.; Devi, S.K.; Singh, L.R. Silk Protein Sericin: Structure, Secretion, Composition and Antimicrobial Potential. Front. Anti-Infect. Agents 2019, 1, 183-194. [CrossRef]

10. El-Fakharany, E.M.; Abu-Elreesh, G.M.; Kamoun, E.A.; Zaki, S.; Abd-El-Haleem, D.A. In vitro assessment of the bioactivities of sericin protein extracted from a bacterial silk-like biopolymer. RSC Adv. 2020, 10, 5098-5107. [CrossRef]

11. Chlapanidas, T.; Faragò, S.; Lucconi, G.; Perteghella, S.; Galuzzi, M.; Mantelli, M.; Avanzini, M.A.; Tosca, M.C.; Marazzi, M.; Vigo, D.; et al. Sericins exhibit ROS-scavenging, anti-tyrosinase, anti-elastase, and in vitro immunomodulatory activities. Int. J. Biol. Macromol. 2013, 58, 47-56. [CrossRef]

12. Ahamad, M.S.I.; Vootla, S. Extraction and evaluation of antimicrobial potential of antheraeamylitta silk sericin. Inter J Recent Sci Res 2018, 9, 32019-32022.

13. Kunz, R.I.; Brancalhão, R.M.C.; Ribeiro, L.D.F.C.; Natali, M.R.M. Silkworm Sericin: Properties and Biomedical Applications. BioMed Res. Int. 2016, 2016, 8175701. [CrossRef]

14. Chithrashree, G.C.; Kumar, M.S.; Sharada, A.C. Sericin, a Versatile Protein from Silkworm—Biomedical Applications. Shanlax Int. J. Arts, Sci. Humanit. 2021, 8, 6-11. [CrossRef]

15. Griffin, D.W. The Quest for Extraterrestrial Life: What About the Viruses? Astrobiology 2013, 13, 774-783. [CrossRef] [PubMed]

16. World Health Organisation (WHO). Progress Report on HIV, Viral Hepatitis and Sexually Transmitted Infections 2019: Accountability for the Global Health Sector Strategies, 2016-2021; WHO: Geneva, Switzerland, 2019.

17. Forsythe, S.S.; McGreevey, W.; Whiteside, A.; Shah, M.; Cohen, J.; Hecht, R.; Bollinger, L.A.; Kinghorn, A. Twenty Years of Antiretroviral Therapy for People Living With HIV: Global Costs, Health Achievements, Economic Benefits. Health Aff. 2019, 38, 1163-1172. [CrossRef] [PubMed]

18. Ehwarieme, R.; Agarwal, A.N.; Alkhateb, R.; Bowling, J.E.; Anstead, G.M. A Surprising Cause of Liver Abscesses in a PostChemotherapy Patient: Herpes Simplex Virus. Cureus 2021, 13. [CrossRef]

19. El-Tantawy, W.H.; Temraz, A. Natural products for the management of the hepatitis C virus: A biochemical review. Arch. Physiol. Biochem. 2018, 126, 116-128. [CrossRef] [PubMed]

20. Tovo, P.-A.; Calitri, C.; Scolfaro, C.; Gabiano, C.; Garazzino, S. Vertically acquired hepatitis C virus infection: Correlates of transmission and disease progression. World J. Gastroenterol. 2016, 22, 1382-1392. [CrossRef]

21. El Fakharany, E.; El-Baky, N.A.; Linjawi, M.H.; AlJaddawi, A.A.; Saleem, T.H.; Nassar, A.Y.; Osman, A.; Redwan, E.M. Influence of camel milk on the hepatitis C virus burden of infected patients. Exp. Ther. Med. 2017, 13, 1313-1320. [CrossRef]

22. Redwan, E.M.; Uversky, V.N.; El-Fakharany, E.M.; Al-Mehdar, H. Potential lactoferrin activity against pathogenic viruses. Comptes Rendus. Biol. 2014, 337, 581-595. [CrossRef] [PubMed]

23. El-Fakharany, E.M. Nanoformulation of lactoferrin potentiates its activity and enhances novel biotechnological applications. Int. J. Biol. Macromol. 2020, 165, 970-984. [CrossRef]

24. Saad, M.H.; El-Fakharany, E.M.; Salem, M.S.; Sidkey, N.M. The use of cyanobacterial metabolites as natural medical and biotechnological tools: Review article. J. Biomol. Struct. Dyn. 2020, 1-23. [CrossRef] [PubMed]

25. El-Fakharany, E.M. Nanoformulation approach for improved stability and efficiency of lactoperoxidase. Preparative Biochemistry Biotechnology 2020, 51, 629-641. [CrossRef] 
26. El-Fakharany, E.M.; Saad, M.H.; Salem, M.S.; Sidkey, N.M. Biochemical characterization and application of a novel lectin from the cyanobacterium Lyngabya confervoides MK012409 as an antiviral and anticancer agent. Int. J. Biol. Macromol. 2020, 161, 417-430. [CrossRef]

27. Saad, M.H.; El-Fakharany, E.M.; Salem, M.S.; Sidkey, N.M. In vitro assessment of dual (antiviral and antitumor) activity of a novel lectin produced by the newly cyanobacterium isolate, Oscillatoria acuminate MHM-632 MK014210.1. J. Biomol. Struct. Dyn. 2020, 1-21. [CrossRef]

28. El-Maradny, Y.A.; El-Fakharany, E.M.; Abu-Serie, M.M.; Hashish, M.H.; Selim, H.S. Lectins purified from medicinal and edible mushrooms: Insights into their antiviral activity against pathogenic viruses. Int. J. Biol. Macromol. 2021, 179, 239-258. [CrossRef] [PubMed]

29. Kamoun, E.A.; Abu-Elreesh, G.M.; El-Fakharany, E.M.; Abd-El-Haleem, D. A Novel Bacterial Polymeric Silk-Like Protein from a Petroleum Origin Bacillus sp. strain NE: Isolation and Characterization. J. Polym. Environ. 2019, 27, 1629-1641. [CrossRef]

30. Zaki, S.; Farag, S.; Abu Elreesh, G.; Elkady, M.; Nosier, M.; El Abd, D. Characterization of bioflocculants produced by bacteria isolated from crude petroleum oil. Int. J. Environ. Sci. Technol. 2011, 8, 831-840. [CrossRef]

31. Lohr, H.F.; Goergen, B.; Biischenfelde, K.-H.M.Z.; Gerken, G. HCV replication in mononuclear cells stimulates anti-HCV-secreting $B$ cells and reflects nonresponsiveness to interferon- $\alpha$. J. Med. Virol. 1995, 46, 314-320. [CrossRef]

32. Mosmann, T. Rapid colorimetric assay for cellular growth and survival: Application to proliferation and cytotoxicity assays. $J$. Immunol. Methods 1983, 65, 55-63. [CrossRef]

33. Redwan, E.M.; Almehdar, H.A.; El-Fakharany, E.M.; Baig, A.-W.K.; Uversky, V.N. Potential antiviral activities of camel, bovine, and human lactoperoxidases against hepatitis C virus genotype 4. RSC Adv. 2015, 5, 60441-60452. [CrossRef]

34. Abdallah, A.E.; Alesawy, M.S.; Eissa, S.I.; El-Fakharany, E.M.; Kalaba, M.H.; Sharaf, M.H.; Shama, N.M.A.; Mahmoud, S.H.; Mostafa, A.; Al-Karmalawy, A.A.; et al. Design and synthesis of new 4-(2-nitrophenoxy)benzamide derivatives as potential antiviral agents: Molecular modeling and in vitro antiviral screening. New J. Chem. 2021, 45, 16557-16571. [CrossRef]

35. Ramakrishnan, M.A. Determination of 50\% endpoint titer using a simple formula. World J. Virol. 2016, 5, 85-86. [CrossRef]

36. Kessler, H.H.; Mühlbauer, G.; Rinner, B.; Stelzl, E.; Berger, A.; Dörr, H.-W.; Santner, B.; Marth, E.; Rabenau, H. Detection of Herpes Simplex Virus DNA by Real-Time PCR. J. Clin. Microbiol. 2000, 38, 2638-2642. [CrossRef]

37. Heim, A.; Ebnet, C.; Harste, G.; Pring-Åkerblom, P. Rapid and quantitative detection of human adenovirus DNA by real-time PCR. J. Med. Virol. 2003, 70, 228-239. [CrossRef]

38. Mentel, R.; Kurek, S.; Wegner, U.; Janta-Lipinski, M.V.; Gürtler, L.; Matthes, E. Inhibition of adenovirus DNA polymerase by modified nucleoside triphosphate analogs correlate with their antiviral effects on cellular level. Med. Microbiol. Immunol. 2000, 189, 91-95. [CrossRef] [PubMed]

39. Schnute, M.E.; Anderson, D.J.; Brideau, R.J.; Ciske, F.L.; Collier, S.A.; Cudahy, M.M.; Eggen, M.; Genin, M.J.; Hopkins, T.A.; Judge, T.M.; et al. 2-Aryl-2-hydroxyethylamine substituted 4-oxo-4,7-dihydrothieno[2,3-b]pyridines as broad-spectrum inhibitors of human herpesvirus polymerases. Bioorganic Med. Chem. Lett. 2007, 17, 3349-3353. [CrossRef]

40. Knopf, K.-W. Properties of Herpes Simplex Virus DNA Polymerase and Characterization of Its Associated Exonuclease Activity. JBIC J. Biol. Inorg. Chem. 1979, 98, 231-244. [CrossRef]

41. Redwan, E.M.; El-Fakharany, E.M.; Uversky, V.N.; Linjawi, M.H. Screening the anti infectivity potentials of native N- and C-lobes derived from the camel lactoferrin against hepatitis C virus. BMC Complement. Altern. Med. 2014, 14, 219. [CrossRef]

42. Pradel, F.; Paranhos-Baccalà, G.; Sodoyer, M.; Chevallier, P.; Mandrand, B.; Lotteau, V.; André, P. Quantitation of HCV RNA using real-time PCR and fluorimetry. J. Virol. Methods 2001, 95, 111-119. [CrossRef]

43. Anticoli, S.; Amatore, D.; Matarrese, P.; De Angelis, M.; Palamara, A.T.; Nencioni, L.; Ruggieri, A. Counteraction of HCV-Induced Oxidative Stress Concurs to Establish Chronic Infection in Liver Cell Cultures. Oxid. Med. Cell. Longev. 2019, 2019, 6452390. [CrossRef]

44. Jastrzebska, K.; Kucharczyk, K.; Florczak, A.; Dondajewska, E.; Mackiewicz, A.; Dams-Kozlowska, H. Silk as an innovative biomaterial for cancer therapy. Rep. Pr. Oncol. Radiother. 2015, 20, 87-98. [CrossRef]

45. Agarwal, N.; Hoagland, D.A.; Farris, R.J. Effect of moisture absorption on the thermal properties of Bombyx mori silk fibroin films. J. Appl. Polym. Sci. 1997, 63, 401-410. [CrossRef]

46. Waterhouse, A.; Bertoni, M.; Bienert, S.; Studer, G.; Tauriello, G.; Gumienny, R.; Heer, F.T.; De Beer, T.A.P.; Rempfer, C.; Bordoli, L.; et al. SWISS-MODEL: Homology modelling of protein structures and complexes. Nucleic Acids Res. 2018, 46, W296-W303. [CrossRef]

47. Laskowski, R.A.; MacArthur, M.W.; Moss, D.S.; Thornton, J.M. PROCHECK: A program to check the stereochemical quality of protein structures. J. Appl. Crystallogr. 1993, 26, 283-291. [CrossRef]

48. Laskowski, R.A.; Jabłońska, J.; Pravda, L.; Vařeková, R.S.; Thornton, J. PDBsum: Structural summaries of PDB entries. Protein Sci. 2018, 27, 129-134. [CrossRef] [PubMed]

49. Wilkins, M.R.; Gasteiger, E.; Bairoch, A.; Sanchez, J.-C.; Williams, K.L.; Appel, R.D.; Hochstrasser, D.F. Protein Identification and Analysis Tools in the ExPASy Server. In 2-D Proteome Analysis Protocols; Methods in Molecular Biology; Humana Press: Totowa, NJ, USA, 1999; Volume 112, pp. 531-552. [CrossRef]

50. Tovchigrechko, A.; Vakser, I.A. GRAMM-X public web server for protein-protein docking. Nucleic Acids Res. 2006, 34, W310-W314. [CrossRef] 
51. Krissinel, E.; Henrick, K. Inference of Macromolecular Assemblies from Crystalline State. J. Mol. Biol. 2007, 372, 774-797. [CrossRef] [PubMed]

52. Moraes, J.P.A.; Pappa, G.L.; Pires, D.E.V.; Izidoro, S.C. GASS-WEB: A web server for identifying enzyme active sites based on genetic algorithms. Nucleic Acids Res. 2017, 45, W315-W319. [CrossRef] [PubMed]

53. Fahnestock, S.R.; Yao, Z.; Bedzyk, L.A. Microbial production of spider silk proteins. Rev. Mol. Biotechnol. 2000, 74, 105-119. [CrossRef]

54. Yang, Y.J.; Choi, Y.S.; Jung, D.; Park, B.R.; Hwang, W.B.; Kim, H.W.; Cha, H.J. Production of a novel silk-like protein from sea anemone and fabrication of wet-spun and electrospun marine-derived silk fibers. NPG Asia Mater. 2013, 5, e50. [CrossRef]

55. Antony, V.A.R.; Chinnamal, S.K. Enzymatic degumming of silk using Bacillus sp. Int. J. Sci. Tech. Mang. 2015, 4, 458-465.

56. Sharma, R. Enzyme Inhibition: Mechanisms and Scope. In Enzyme Inhibition and Bioapplications; IntechOpen: London, UK, 2012.

57. Fan, J.-B.; Wu, L.-P.; Chen, L.-S.; Mao, X.-Y.; Ren, F.-Z. Antioxidant Activities of Silk Sericin from Silkwormbombyx MorI. J. Food Biochem. 2009, 33, 74-88. [CrossRef]

58. Da Silva, T.L.; Da Silva, A.C.; Ribani, M.; Vieira, M.G.A.; Gimenes, M.L.; Da Silva, M.G.C. Evaluation of molecular weight distribution of sericin in solutions concentrated via precipitation by ethanol and precipitation by freezing/thawing. Chem. Eng. Trans. 2014, 38, 103-108.

59. Turbiani, F.R.B.; Tomadon, J.; Seixas, F.L.; Gimenes, M.L. Properties and structure of sericin films: Effect of the crosslinking degree. In Proceedings of the 10th International Conference on Chemical and Process Engineering, Moscow, Russian, $28-30$ April 2011. 